\title{
Analisis Pengaruh Shariah Compliance dan Assurance terhadap Kepuasan Nasabah BMT Barokatul Umah di Kabupaten Merauke
}

\section{Orin Verawati Ramadani}

Universitas Musamus Merauke

email: orinramadani020@gmail.com

\author{
Abd Rahman Kadir \\ Universitas Hasanuddin Makassar \\ email: rahmankadir90@yahoo.com
}

\author{
Abdullah Sanusi \\ Universitas Hasanuddin Makassar \\ email: a.sanusi@unhas.ac.id
}

\begin{abstract}
This study aims to determine the effect of Shariah Compliance and Assurance on customer satisfaction partially and simultaneously. In this study using a quantitative approach and multiple linear regression. The object of this research is the employees and customers of BMT Barokatul Ummah in Merauke Regency. While the data collection techniques are using interviews, questionnaires, and literature studies. The results of this study indicate that the Shariah Compliance and Assurance dimension has been implemented well, and has a positive and significant influence on customer satisfaction at the BMT Barokatul Ummah. This means that the Shariah Compliance and Assurance dimensions are further enhanced, customer satisfaction is getting higher.
\end{abstract}

Keywords: Customer satisfaction; Compliance; Assurance

\begin{abstract}
Abstrak: Penelitian ini bertujuan untuk mengetahui pengaruh Shariah Compliance dan Assurance terhadap kepuasan nasabah secara parsial dan simultan. Dalam penelitian ini menggunakan pendekatan kuantitatif dengan regresi linier berganda. Objek dalam penelitian ini adalah pimpinan dan nasabah BMT Barokatul Ummah di Kabupaten Merauke. Sedangkan teknik pengumpulan data yaitu menggunakan wawancara, kuesioner, dan studi kepustakaan. Hasil penelitian ini menunjukkan bahwa dimensi Shariah Compliance dan Assurance telah dijalankan dengan baik, dan mempunyai pengaruh positif dan signifikan kepada kepuasan nasabah pada BMT Barokatul Ummah. Artinya semakin ditingkatkan dimensi Shariah Compliance dan Assurance maka kepuasan nasabah semakin tinggi.
\end{abstract}

Kata Kunci: Kepuasan nasabah, Compliance; Assurance

Economica: Jurnal Ekonomi Islam - Volume 9, Nomor 2 (2018) 


\section{Pendahuluan}

Bank syariah sebagai lembaga bisnis keuangan yang melaksanakan kegiatan usahanya sejalan dengan prinsip-prinsip dasar dalam ekonomi Islam. Kulitas pelayanan yang diberikan oleh seorang karyawan kepada nasabah hendaknya bisa memberikan kepuasan, kenyamanan pada nasabah, sehingga seorang nasabah merasa dirinya dilayani dengan apa yang diingkan oleh nasabah tersebut, seorang karyawan harus memiliki kemampuan yang dapat membuat nasabahnya mempercayai dirinya, jika nasabah merasa percaya akan pelayanan yang diberikan, maka nasabah akan merasa nyaman. Seorang karyawan harus peduli pada nasabah yang membutuhkan pelayanan sehingga dapat mewujudkan keinginan seorang nasabah.

Dalam memberikan kepuasan kepada nasabah, perusahaan perbankan harus dapat meningkatkan kualitas pelayanan dan keunggulan produknya. Semakin baik kualitas pelayanannya, maka semakin tinggi tingkat kepuasan yang dirasakan nasabah terhadap perusahaan perbankan tersebut. Tingkat kepuasan nasabah menjadi tolak ukur keberhasilan suatu perusahaan perbankan tersebut.

Metode pengukuran kualitas pelayanan yang biasa digunakan untuk mengukur kualitas pada perbankan konvensional serta banyak digunakan luas adalah metode SERVQUAL. Metode SERVQUAL didasarkan pada "Gap Model" yang dikembangkan oleh Parasuraman, Zeithaml, dan Berry (1988). Metode SERVQUAL didasarkan pada lima dimensi yaitu, tangible, reliability, responsiveness, assurance, dan empathy. Servqual tidak cukup untuk mengukur kualitas pada perbankan syariah. Othman dan Owen mengembangkan model yang disebut dengan model CARTER. Model CARTER merupakan suatu pengukuran kualitas pelayanan perbankan syariah dengan 6 dimensi yaitu: Compliance, Assurance, Reliability, Tangible, Empathy, dan Responsivenees (Shofani 2015). 
BMT Barokatul Ummah merupakan lembaga keuangan yang bergerak dalam dua prinsip usaha, yaitu Baitul Maal (rumah harta) dan Baitul Tamwil (rumah usaha). Dalam operasinya BMT Barokatul Ummah tidak menggunakan bunga (karena tidak sesuai dengan syariah Islam) akan tetapi menggunakan sistem bagi hasil (mudharabah) dan jual beli (murabahah). BMT Barokatul Ummah ini dijalankan dengan mengikuti tata cara berusaha dan perjanjian usaha sesuai dengan Al Qur'an dan Al Hadist.

Di Kabupaten Merauke perkembangan BMT Barokatul Ummah masih lambat. Sampai sekarang di kota Merauke hanya ada satu kantor BMT Barokatul Ummah yaitu di jalan Timur Kabupaten Merauke. BMT tersebut belum dikenal oleh semua masyarakat kota Merauke. Karena kurangnya tingkat pendidikan yang tinggi sehingga masyarakat masih banyak yang belum mengerti tentang ketentuan dan peraturan bank syariah, dan banyaknya bank konvensional di kabupaten merauke, dan kurangnya sosialisasi dari pihak BMT Barokatul Ummah kepada masyarakat dan sebagian besar mayoritas di kota merauke beragama non muslim. Inilah yang menjadi tantangan bagi bmt barokatul ummah di kabupaten merauke untuk tetap berdiri dan menjalankan manajemen perbankannya.

BMT belum sepenuhnya menggunakan teknologi informasi dalam menjalankan operasional karena masih terbatasnya jaringan internet sehingga membuat pelayanan yang ada di BMT sedikit keterkendala. Dokumen-dokumen yang ada di BMT sebagian besar masih menggunkan cara manual dalam mengelola datanya sehingga membuat pegawai bmt ini memerlukan waktu yang cukup lama untuk menyelesaikan pekerjaannya dan pelayanan kepada para nasabahnya. Penelitian yang dilakukan oleh Febriana (2016) mengatakan bahwa dimensi Assurance berpengaruh dominan terhadap kepuasan nasabah BMI KCP Tulungagung. Sehingga dapat disimpulkan bahwa tingkat nasabah BMI KCP Tulungagung dipengaruhi oleh kualitas pelayanan yang diberikan oleh BMI KCP Tulungagung yang terangkum dalam 6 dimensi CARTER. 
Orin Verawati Ramadani, Abd Rahman Kadir, Abdullah Sanusi

Berdasarkan masalah yang terdapat di atas penulis melakukan penelitian dengan judul: "Analisis Pengaruh Shariah Compliance dan Assurance terhadap Kepuasan Nasabah BMT Barokatul Umah Di Kabupaten Merauke".

Tujuan parsial penelitian ini adalah untuk mengetahui pengaruh shariah Compliance terhadap kepuasan nasabah, dan untuk mengetahui pengaruh Assurance terhadap kepuasan nasabah, dan untuk tujuan simultannya adalah untuk mengetahui pengaruh shariah Compliance dan Assurance terhadap kepuasan nasabah.

\section{Landasan Teori}

\section{Servqual}

Servqual (Service Quality) yang dikembangkan oleh Parasuraman, Zeithaml, dan Berry (1988) dikenal dengan istilah gap analisis model ini berkaitan erat dengan model kepuasan pelanggan yang didasarkan pada ancangan diskonfirmasi. Kualitas pelayanan merupakan fungsi gap antara harapan konsumen terhadap layanan dan persepsi mereka terhadap layanan aktual yang dihasilkan suatu perusahaan. Harapan konsumen terhadap layanan merupakan keinginan atau permintaan ideal konsumen terhadap layanan yang akan diberikan oleh penyedia layanan (Muchtiar, Mufti, and Suryani 2012). Terdapat lima dimensi pokok kualitas pelayan (Parasuraman, Zeithaml, and Berry 1988), diantaranya adalah:

1. Tangible penampakan fasilitas dan peralatan secara fisik yang digunakan untuk menyediakan atau memberikan pelayanan.

2. Reliability yakni kemampuan untuk menyajikan pelayanan secara tepat, benar, dan akurat.

3. Responsiveness yakni keinginan para staf untuk membantu para pelanggan dan memberikan pelayanan dengan tanggap. 
4. Assyrance yakni jaminan dan sifat dapat dipercaya yang dimiliki oleh perusahaan.

5. Empathy meliputi kemudahan dalam melakukan hubungan komunikasi yang baik, perhatian pribadi dan memahami kebutuhan para pelanggan.

\section{Dimensi CARTER}

Othman dan Owen Shofani (2015) mengembangkan model yang disebut dengan model CARTER. Model CARTER merupakan suatu pengukuran kualitas pelayanan perbankan syariah dengan 6 dimensi yaitu: Compliance, Assurance, Reliability, Tangible, Empathy, dan Responsivenees.

\section{Compliance}

Compliance adalah kemampuan untuk memenuhi hukum islam dalam beroperasi berdasarkan prinsip-prinsip ekonomi dan perbankan Islam. Indikator variabel Compliance adalah sebagai berikut: Pertama sesuai dengan hukum dan prinsip-prinsip Islam. Kedua tidak ada bunga yang diambil ataupun diberikan pada atau tabungan. Ketiga ketersediaan produk investasi bagi hasil.

\section{Assurance}

Assurance adalah pengetahuan dan kesopanan karyawan dan kemampuan mereka untuk menyampaikan kepercayaan dan keinginan yang didalamnya termasuk komunikasi variabel dan tertulis antara karyawan dan nasabah. Indikator Assurance adalah sebagai berikut: Pertama karyawan yang sopan dan ramah. Kedua karyawan yang mengetahui produk bank. Ketiga bank memberikan kerahasiaan data nasabah. Keempat bank memberikan saran produk yang terbaik. 


\section{Reliability}

Reliability yaitu kemampuan perusahaan untuk memberikan pelayanan sesuai yang dijanjikan secara akurat dan terpercaya. Kinerja harus sesuai dengan harapan pelanggan yang berarti ketepatan waktu, pelayanan yang sama untuk semua pelanggan tanpa kesalahan, sikap yang simpatik, dan dengan akurasi yang tinggi.

\section{Tangible}

Tangible adalah penampilan komponen fisik. Penampilan fisik ini termasuk didalamnya sarana dan prasarana fisik perusahaan yang dapat diandalkan keadaan lingkungan sehingga menampilkan pelayanan yang diberikan oleh pembeli jasa.

\section{Empathy}

Empathy adalah peduli, perhatian individual yang bank syariah sediakan bagi pelanggannya.

\section{Responsiveness}

Responsiveness adalah suatu kemampuan untuk membantu dan memberikan pelayanan yang cepat dan tepat kepada pelanggan, dengan penyampaian informasi yang jelas.

\section{Kepuasan Nasabah}

Menurut Hasanah (2013) kepuasan atau ketidak puasan adalah respon pelanggan terhadap evaluasi ketidaksesuaian yang dirasakan antara harapa sebelumnya dan kinerja aktual produk yang dirasakan setelah pemakaiannya. Kepuasan konsumen adalah tingkat perasaan seseorang setelah membandingkan kinerja (hasil) yang dirasakan, dibandingkan dengan harapan (Daryanto 2011). Kepuasan adalah hasil dari penilaian konsumen bahwa produk atau jasa pelayanan telah memberikan tingkat 
Analisis Pengaruh Shariah Compliance dan Assurance....

kenikmatan dimana tinggat pemenuhan ini bisa lebih atau kurang (Sudaryono 2016).

\section{Penelitian Terdahulu}

Febriana (2016) Dengan judul "Analisis Kualitas Pelayanan Bank terhadap Kepuasan Nasabah pada Bank Muamalat Indonesia Kantor Cabang Pembantu Tulungagung”. Penelitian ini menggunakan metode analisis Serqual (analisis gap).

Hasil dari penelitian ini adalah terdapat kesenjangan antara harapan dengan persepsi nasabah atas kualitas pelayanan yang selama ini diberikan oleh pihak BMI KCP Tulungagung, sehingga dapat disimpulkan bahwa harapan nasabah atas kualitas pelayanan yang akan mereka terima di BMI KCP Tulungagung lebih tinggi daripada kualitas pelayanan yang telah diberikan BMI KCP Tulungagung. Hal tersebut dapat dilihat pada hasil analisis gap yang menunjukkan bahwa pada masing-masing dimensi kualitas pelayanan memiliki kesenjangan atau (gap) antara harapan nasabah dengan kinerja atas pelayanan yang diberikan oleh BMI KCP Tulugagung

Cahyani (2016) Dengan judul "Tingkat Kepuasan Nasabah terhadap Kualitas Layanan Perbankan Syariah Di Yogyakarta”. Penelitian ini menggunakan metode analisis jalur.

Hasil dari penelitian ini adalah kualitas layanan bank serta kepuasan yang dirasakan nasabah kepada bank syariah sudah diatas moderat. Faktorfaktor kualitas jasa yang memberikan kepuasan nasabah terbesar sampai yang terkecil adalah responsiveness, Compliance, emphaty, tanggible, reliabioity dan assurance. Pemberian kemudahan dalam konsultasi keuangan dan produk bebas bunga sesuai dengan syariah menjadi aspek prioritas pembentuk kepuasan nasabah dalam melakukan transaksi di bank syariah.

Dalam analisis varian dapat disimpulkan bahwa persepsi nasabah terhadap kualitas pada empat bank dianggap tidak signifikan. Kualitas dari

Economica: Jurnal Ekonomi Islam - Volume 9, Nomor 2 (2018) 
tiap bank dianggap tidak ada perbedaan. Sama halnya dengan uji perbedaan terhadap kepuasan nasabah pada masing-masing bank syariah, dapat disimpulkan bahwa kepuasan yang dirasakan oleh nasabah pada tiap bank syariah tidak ada perbedaan.

Rohmati and Fanani (2016). Dengan judul "Imlementasi Kualitas Pelayanan Pendekatan Carter Dan Pengaruhnya Terhadap Kepuasan UJKS Koperasi Karyawan". Penelitian ini menggunakan metode regresi berganda dan analisis jalur.

Hasil dari penelitian ini adalah dimensi reliabilitas dan daya tanggap secara parsial berpengaruh signifikan terhadap tingkat kepuasan anggota. Namun, dimensi tangibles, assurance, empathy dan kepatuhan syariah tidak berpengaruh signifikan terhadap kepuasan anggota.

\section{Hipotesis Penelitian}

Bertitik tolak dari pembahasan terdahulu, maka dapat diungkap bahwa terdapat keterkaitan antara Compliance dan Assurance dalam meningkatkan kepuasan nasabah. Atas dasar kerangka pemikiran teoritis tersebut, maka hipotesis yang diuji dalam penelitian ini adalah:

$\mathrm{H}_{1} \quad$ : Compliance berpengaruh secara positif dan signifikan terhadap meningkatkan Kepuasan Nasabah.

$\mathrm{H}_{2} \quad$ : Assurance berpengaruhi secara positif dan signifikan terhadap meningkatkan Kepuasan Nasabah.

$\mathrm{H}_{3} \quad$ : Compliance dan Assurance berpengaruh positif dan signifikan terhadap meningkatkan Kepuasan Nasabah.

\section{Metode Penelitian}

\section{Jenis Penelitian}

Rancangan penelitian ini menggunakan penelitian kuantitatif yaitu untuk mengetahui Analisis Pengaruh Shariah Compliance, Assurance 
Terhadap Kepuasan Nasabah. Penelitian ini dilakukan pada nasabah BMT (Barokatul Ummah) di Kabupaten Merauke yang beralamat di Jl. Timur Kabupaten Merauke. Data - data yang dikumpulkan dan digunakan dalam penelitian ini bersifat kuantitatif.

\section{Sumber Data}

Sumber data dalam penelitian ini adalah data primer dan data sekunder sebagai berikut:

1. Data Primer merupakan data yang diperoleh dengan observasi dan angket yang dikumpulkan dari responden.

2. Data Sekunder merupakan data yang di peroleh berupa informasi tertulis, misalnya berupa artikel, data-data langsung dari BMT Barokatul Ummah di Kabupaten Merauke

\section{Populasi dan Sampel}

Populasi dalam penelitian ini adalah nasabah BMT (Barokatul Ummah) di Kabupaten Merauke sebanyak 4.508 nasabah. Untuk menentukan jumlah minimal sampel yang dibutuhkan, digunakan rumus Slovin (Sekaran 2006). Dengan jumlah populasi sebanyak 4.508 nasabah, dan untuk menghemat waktu dan biaya, peneliti memutuskan untuk melakukan penelitian dengan menggunakan sampel berdasarkan rumus slovin dan batas toleransi tingkat kesalahan 10\%, maka jumlah sampel adalah: 98 nasabah Bank BMT Barokatul Ummah.

\section{Teknik Pengambilan Sampel}

Teknik sampling atau pengambilan sampel yang digunakan dalam penelitian ini adalah dengan menggunakan sample random sampling (sampel acak sederhana) yaitu setiap elemen populasi memiliki peluang yang sama dan setara untuk terpilih sebagai subjek. 


\section{Definisi dan Pengukuran Variabel}

Menurut Rangkuti (1997) tujuan teknik skala untuk mengetahui ciri-ciri atau karakteristik sesuatu hal berdasarkan suatu ukuran tertentu, sehingga kita dapat membedakan, menggolong-golongkan, bahkan mengurutkan ciriciri dan karakteristik. Dalam penelitian ini, peneliti menggunakan skala Likert. Skala yang digunakan untuk mengukur sikap, pendapat, dan persepsi seseorang atau sekelompok orang tentang fenomen sosial.

Variabel-variabel yang memilki keterikatan yang erat mempengaruhi: Compliance $\left(\mathrm{X}_{1}\right)$, Assurance $\left(\mathrm{X}_{2}\right)$, dan kepuasan nasabah $(\mathrm{Y})$.

Tabel 2. Variabel-variabel Terkait

\begin{tabular}{|c|c|c|c|}
\hline NO & Variabel & Konsep & Indikator \\
\hline 1 & $\begin{array}{r}\text { Compliance } \\
\left(\mathrm{X}_{1}\right)\end{array}$ & $\begin{array}{l}\text { Compliance adalah kemampuan } \\
\text { untuk memenuhi hukum islam } \\
\text { dalam beroperasi berdasarkan } \\
\text { prinsip-prinsip ekonomi dan } \\
\text { perbankan Islam }\end{array}$ & $\begin{array}{l}\text { Sesuai dengan hukum dan prinsip- } \\
\text { prinsip Islam, } \\
\text { Tidak ada bunga yang diambil } \\
\text { ataupun diberikan pada atau } \\
\text { tabungan, dan } \\
\text { Ketersediaan produk investasi bagi } \\
\text { hasil. }\end{array}$ \\
\hline 2 & $\begin{array}{r}\text { Assurance } \\
\left(\mathrm{X}_{2}\right)\end{array}$ & $\begin{array}{l}\text { Assurance adalah pengetahuan } \\
\text { dan kesopanan karyawan dan } \\
\text { kemampuan mereka untuk } \\
\text { menyampaikan kepercayaan } \\
\text { dan keinginan yang didalamnya } \\
\text { termasuk komunikasi variabel } \\
\text { dan tertulis antara karyawan } \\
\text { dan nasabah. }\end{array}$ & $\begin{array}{l}\text { Karyawan yang sopan dan ramah, } \\
\text { Karyawan yang mengetahui produk } \\
\text { bank, } \\
\text { Bank memberikan kerahasiaan data } \\
\text { nasabah, dan } \\
\text { Bank memberikan saran produk yang } \\
\text { terbaik. }\end{array}$ \\
\hline 3 & $\begin{array}{r}\text { Kepuasan } \\
\text { Nasabah } \\
(\mathrm{Y})\end{array}$ & $\begin{array}{l}\text { Kepuasan nasabah sebagai } \\
\text { evaluasi purna beli dimana } \\
\text { alternatif yang dipilih sekurang- } \\
\text { kurangnya sama atau } \\
\text { melampaui harapan nasabah, } \\
\text { sedangkan ketidakpuasan } \\
\text { timbul apabila hasil tidak } \\
\text { memenuhi harapan nasabah. }\end{array}$ & $\begin{array}{l}\text { Puas dengan tingkat keuntungan yang } \\
\text { ditawarkan oleh bank syariah, } \\
\text { Bank syariah memberikan jaminan } \\
\text { kepada produk mereka patuh } \\
\text { terhadap ketentuan syariah, dan } \\
\text { Syarat dan ketentuan yang diterapkan } \\
\text { oleh bank syariah dapat diterima. }\end{array}$ \\
\hline
\end{tabular}


Analisis Pengaruh Shariah Compliance dan Assurance....

\section{Teknik Analisis data}

Suatu data yang diperoleh agar lebih dapat bermanfaat, data harus dianalisis terlebih dahulu agar dapat dijadikan dasar pengambilan keputusan. Metode yang digunakan dalam penelitian ini adalah metode analisis data kuantitatif dengan bantuan program Computer SPSS 20.0.

\section{Hasil dan Pembahasan}

\section{Barokatul Ummah Merauke}

BMT Barokatul Ummah merupakan lembaga keuangan yang bergerak dalam dua prinsip usaha, yaitu Baitul Maal (rumah harta) dan Baitul Tamwil (rumah usaha). Dalam operasinya BMT Barokatul Ummah tidak menggunakan bunga (karena tidak sesuai dengan syariah Islam) akan tetapi menggunakan sistem bagi hasil (mudharabah) dan jual beli (murabahah). BMT Barokatul Ummah ini dijalankan dengan mengikuti tata cara berusaha dan perjanjian usaha sesuai dengan Al Qur'an dan Al Hadist:

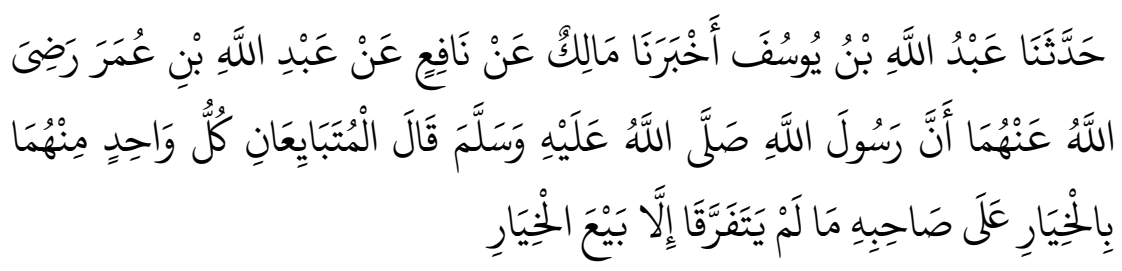

"Telah menceritakan kepada kami 'Abdullah bin Yusuf telah mengabarkan kepada kami Malik dari Nafi' dari 'Abdullah bin 'Umar radhiyallahu 'anhu bahwa Rasulullah shallallahu 'alaihi wasallam bersabda: Dua orang yang melakukan jual beli, masing-masing punya hak pilihan atas teman jual belinya selama keduanya belum berpisah, kecuali jual beli yang tidak membutuhkan berpisah." (HR. Bukhari)

Keberadaan BMT Barokatul Ummah tidak terlepas dari kebersamaan masyarakat yang ingin membentuk suatu wadah yang berbentuk lembaga jasa keuangan syariah di Merauke.

Economica: Jurnal Ekonomi Islam - Volume 9, Nomor 2 (2018) 
Orin Verawati Ramadani, Abd Rahman Kadir, Abdullah Sanusi

Gambar 1. Distribusi Responden Berdasarkan Jenis Kelamin N = 98

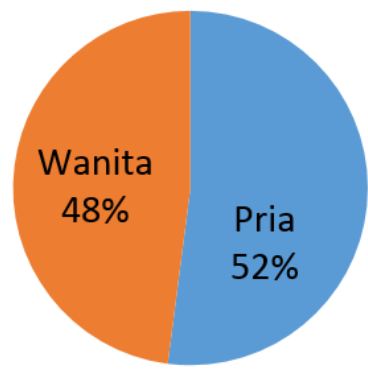

Sumber: Data diolah, 2018

Berdasarkan gambar 1 dapat dilihat bahwa nasabah pria lebih banyak dibandingkan dengan nasabah wanita. Hal tersebut ditemukan pada lembaran kuesioner yang dibagikan, alasannya karena nasabah pria lebih senang melakukan transaksi dan menabung sebagian penghasilannya dibandingkan dengan nasabah wanita. Karena pria memiliki tingkat membelanjakan uang lebih rendah dibandingkan wanita yang lebih senang menghabiskan uangnya untuk berbelanja.

Gambar 2. Distribusi Responden Berdasarkan Pendidikan N = 98

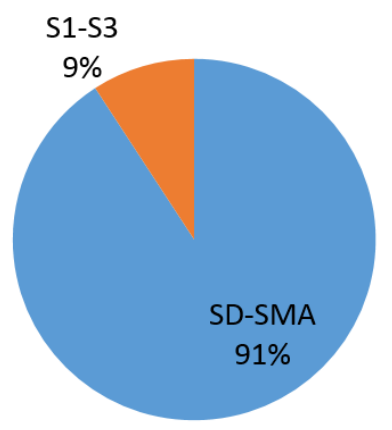

Sumber: Data diolah, 2018

Gambar 2 mengambarkan bahwa nasabah dengan tingkat pendidikan SD-SMA cenderung lebih dominan dibanding dengan S1-S3, hal ini sesuaia dengan target BMT Barokatul Ummah, yakni masyarakat menengah ke 
bawah yang berdomisili di daerah perkampungan. Hasil persentasinya adalah rata-rata SD-SMA sebanyak 89 responden atau 91\% dan jumlah S1-S3 hanya 9 responden atau 9\%. Karena tingkat pendidikan di Merauke masih rendah terbukti dengan kurangnya perguruan tinggi dan kesadaran masyarakat akan pendidikan.

Gambar 3. Distribusi Responden Berdasarkan Usia N $=98$

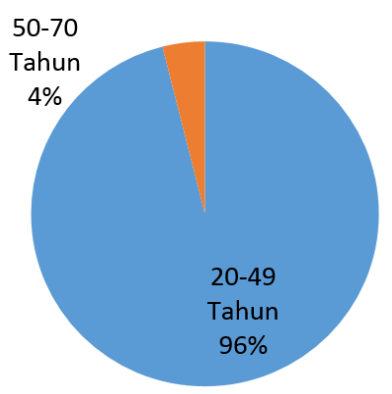

Sumber: Data diolah, 2018

Berdasarkan Gambat 3 dapat dilihat bahwa usia nasaba yang bersekitar 20-49 lebih banyak dibanding dengan usia 50-70. Bila dipersentasikan nasaba uisa 20-49 sebanyak 78 responden atau 80\% sedangkan jumlah nasaba usia 50-70 hanya 20 responden atau 20\%. Karena usia 20-49 adalah usia produktif, dan sebagian nasabahnya memiliki pekerjaan.

Gambar 4. Distribusi Responden Berdasarkan Pekerjaan N = 98

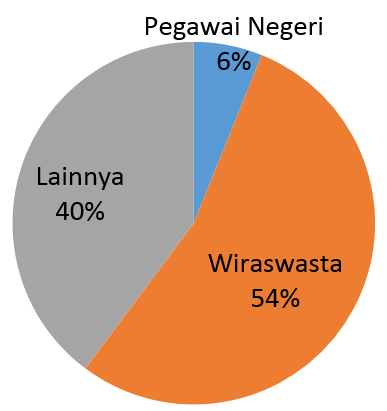

Sumber: Data diolah, 2018

Economica: Jurnal Ekonomi Islam - Volume 9, Nomor 2 (2018) http://journal.walisongo.ac.id/index.php/economica 
Berdasarkan gambar 4 dapat dilihat bahwa pekerjaan nasaba sebagian besar adalah wiraswasta. Dengan jumlah nasaba wiraswasta sebanyak 53 responden atau 54\%, sedangkan 6 reponden atau 6\% adalah nasaba yang bekerja sebagai pegawai. Sisanya masuk dalam kategori pekerjaan lainnya yang respodennya 39 orang atau $40 \%$.

Nasabah yang bekerja sebagai wiraswasta lebih memilih Bank BMT Barokatul Ummah untuk menabung rata-rata memiliki alasan karena bank ini tidak terlalu membutuhkan waktu mengantri cukup lama seperti bank bank lain.

\section{Uji Validitas dan Reliabilitas}

\section{Uji Validitas}

Validiitas adalah syarat untuk penelitian kuantitatif dan kualitatif (dalam penelitian naturalistik). validitas berdasarkan pandangan bahwa pada dasarnya suatu instrumen dapat mengukur apa yang seharusnya dimaksudkan untuk diukur (Sinambela dan Lijan 2014).

Menurut Sujarweni (2015) Uji validitas mengunakan rumus teknik Kolerasi Product Moment.

Dasar pengambilan keputusan adalah:

1. Jika $r_{\text {hitung }}>r_{\text {tabel }}$ maka pernyataan valid

2. Jika $r_{\text {hitung }}<r_{\text {tabel; }}$ maka pernyataan tidak valid

Pengujian validitas merupakan analisis terhadap suatu ukuran yang menunjukkan tingkat kevalidan dan kesahilan suatu kuesioner. Menurut Jogiyanto Haryanto (2013) validitas menunjukkan seberapa jauh suatu tes atau operasi-operasi mengukur apa yang seharusnya diukur. Analisis validitas (lampiran) dilakukan terhadap instrument dimensi Compliance, Assurance dan kepuasan nasabah melalui alat bantu program hitung SPSS 20. 
Tabel 5. Hasil Pengujian Validitas

Correlations

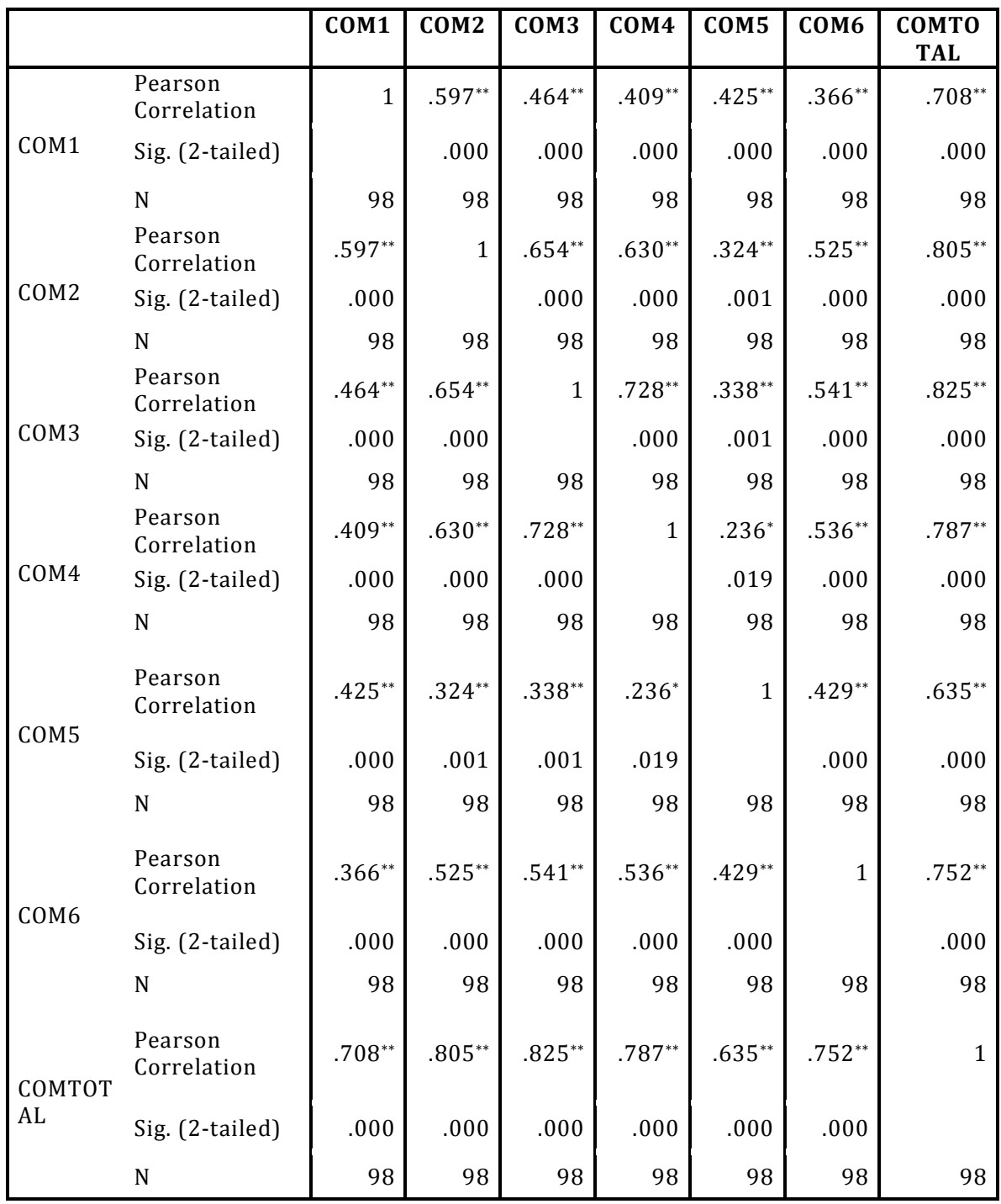

Sumber: Hasil Penelitian, 2018 (data diolah pada SPSS 20)

Economica: Jurnal Ekonomi Islam - Volume 9, Nomor 2 (2018) 
Orin Verawati Ramadani, Abd Rahman Kadir, Abdullah Sanusi

Correlations

\begin{tabular}{|c|c|c|c|c|c|c|}
\hline & & AS1 & AS2 & AS3 & AS4 & ASTOTAL \\
\hline & Pearson Correlation & 1 & $.617^{* *}$ & $.526^{* *}$ & $.518^{* *}$ & $.809^{* *}$ \\
\hline \multirow[t]{3}{*}{ AS1 } & Sig. (2-tailed) & & .000 & .000 & .000 & .000 \\
\hline & $\mathrm{N}$ & 98 & 98 & 98 & 98 & 98 \\
\hline & Pearson Correlation & $.617^{* *}$ & 1 & $.578^{* *}$ & $.628^{* *}$ & $.858^{* *}$ \\
\hline \multirow[t]{3}{*}{ AS2 } & Sig. (2-tailed) & .000 & & .000 & .000 & .000 \\
\hline & $\mathrm{N}$ & 98 & 98 & 98 & 98 & 98 \\
\hline & Pearson Correlation & $.526^{* *}$ & $.578^{* *}$ & 1 & $.522^{* *}$ & $.798^{* *}$ \\
\hline \multirow[t]{3}{*}{ AS3 } & Sig. (2-tailed) & .000 & .000 & & .000 & .000 \\
\hline & $\mathrm{N}$ & 98 & 98 & 98 & 98 & 98 \\
\hline & Pearson Correlation & $.518^{* *}$ & $.628^{* *}$ & $.522^{* *}$ & 1 & $.818^{* *}$ \\
\hline \multirow[t]{3}{*}{ AS 4} & Sig. (2-tailed) & .000 & .000 & .000 & & .000 \\
\hline & $\mathrm{N}$ & 98 & 98 & 98 & 98 & 98 \\
\hline & Pearson Correlation & $.809^{* *}$ & $.858^{* *}$ & $.798^{* *}$ & $.818^{* *}$ & 1 \\
\hline \multirow[t]{2}{*}{ ASTOTAL } & Sig. (2-tailed) & .000 & .000 & .000 & .000 & \\
\hline & $\mathrm{N}$ & 98 & 98 & 98 & 98 & 98 \\
\hline
\end{tabular}

Sumber: Hasil Penelitian, 2018 (data diolah pada SPSS 20)

Correlations

\begin{tabular}{|c|c|c|c|c|c|}
\hline & & $\mathrm{K} 1$ & $\mathrm{~K} 2$ & K3 & KTOTAL \\
\hline \multirow{3}{*}{ K1 } & Pearson Correlation & 1 & $.388^{* *}$ & $.466^{* *}$ & $.777^{* *}$ \\
\hline & Sig. (2-tailed) & & .000 & .000 & .000 \\
\hline & $\mathrm{N}$ & 98 & 98 & 98 & 98 \\
\hline \multirow{3}{*}{ K2 } & Pearson Correlation & $.388^{* *}$ & 1 & $.596^{* *}$ & $.817^{* *}$ \\
\hline & Sig. (2-tailed) & .000 & & .000 & .000 \\
\hline & $\mathrm{N}$ & 98 & 98 & 98 & 98 \\
\hline \multirow{3}{*}{ K3 } & Pearson Correlation & $.466^{* *}$ & $.596^{* *}$ & 1 & $.834^{* *}$ \\
\hline & Sig. (2-tailed) & .000 & .000 & & .000 \\
\hline & $\mathrm{N}$ & 98 & 98 & 98 & 98 \\
\hline \multirow{3}{*}{ KTOTAL } & Pearson Correlation & $.777^{* *}$ & $.817^{* *}$ & $.834^{* *}$ & 1 \\
\hline & Sig. (2-tailed) & .000 & .000 & .000 & \\
\hline & $\mathrm{N}$ & 98 & 98 & 98 & 98 \\
\hline
\end{tabular}

Sumber: Hasil Penelitian, 2018 (data diolah pada SPSS 20) 
Analisis Pengaruh Shariah Compliance dan Assurance....

\section{Uji Reabilitas}

Menurut Sujarweni (2015) reliabilitas instrumen adalah mengukur suatu kekonsistenan hasil pengukuran dari waktu ke waktu. Instrumen yang reliabel dalam suatu penelitian akan menghasilkan data yang sama dari serponden yang serupa dari waktu ke waktu.

Uji reliabilitas merupakan ukuran suat kestabilan dan konsistensi responden dalam menjawab hal yang berkaitan dengan konstruk-konstruk pertanyaan yang merupakan dimensi suatu variable dan disusun dalam suatu kuesioner. Uji reliabilitas dapat dilakukan secara bersama-sama terhadap seluruh butir pertanyaan. Jika nilai Alpha $>0,60$ maka reliabel (Sujarweni 2015).

Jika cronbach'c angka > 0,6 maka reliabel

Jika cronbach'c angka < 0,6 maka tidak reliable

Instrument penelitian juga harus reliable (dapat diandalkan). Reliabilitas suatu ukuran menunjukkan stabilitas dan konsistensi dari suatu instrument yang mengukur suatu konsep. Uji reliabilitas dimasukkan menguji instrument yang sama pada waktu yang berbeda dan memberikan hasil yang sama. Suatu konstruk atau variabel dikatakan reliable jika memberikan nilai Cronbach'c Alpha > 0,6. Berdasarkan hasil pengolahan menggunakan alat bantu program hitung SPSS 20 (lampiran) Cronbach'c Alpha untuk dimensi Compliance $\left(\mathrm{X}_{1}\right)$, Assurance $\left(\mathrm{X}_{2}\right)$, dan Kepuasan Nasabah (Y) yang dapat dilihat pada tabel dibawah ini:

Tabel 6. Hasil Pengujian Reliabilitas

\begin{tabular}{rrc}
\hline Variabel & Koefisien Cronbach'c & Keterangan \\
\hline Compliance $\left(\mathbf{X}_{\mathbf{1}}\right)$ & 0,838 & Reliabilitas \\
\hline Assurance $\left(\mathbf{X}_{\mathbf{2}}\right)$ & 0,838 & Reliabilitas \\
\hline Kepuasan Nasabah $(\mathbf{Y})$ & 0,732 & Reliabilitas \\
\hline
\end{tabular}

Sumber: Hasil Penelitian, 2018 (data diolah pada SPSS 20)

Economica: Jurnal Ekonomi Islam - Volume 9, Nomor 2 (2018) 
Berdasarkan hasil pengujian reliabilitas diatas dapat diketahui bahwa masing-masing dimensi dan variabel, antara dimensi Compliance, Assurance, dan Kepuasan Nasabah, ternyata dapat diperoleh nilai Cronbach'c Alpha $\geq 0,6$ dengan demikian, hasil uji reliabilitas terhadap keseluruhan variabel adalah reliabel.

\section{Analisi Regresi Berganda}

Dalam penelitian ini metode yang digunakan untuk menganalisis yaitu persamaan regresi linier berganda. Untuk menggetahui apakah variabel bebas mempengaruhi volume penjualan. Menurut Ahmad (2004) Rumus regresi linier berganda adalah sebagai berikut:

$Y=a+b_{1} X_{1}+b_{2} X_{2}+b_{3} X_{3}+b_{4} X_{4}+b_{5} X_{5}+b_{6} X_{6}+e$

Dimana:

Y : Kepuasan Nasabah

a : Konstanta

$\mathrm{b}_{1}$ : Koefisien Regresi Compliance

$\mathrm{X}_{1}$ : Compliance

$\mathrm{b}_{2}$ : Koefisien Regresi Assurance

$\mathrm{X}_{2}$ : Assurance

$\mathrm{b}_{3}$ : Koefisien Regresi Reliability

$\mathrm{X}_{3}$ : Reliability

$\mathrm{b}_{4}$ : Koefisien Regresi Tangible

$\mathrm{X}_{4}$ : Tangible

$\mathrm{b}_{5}$ : Koefisien Regresi Empathy

$\mathrm{X}_{5}$ : Empathy

$\mathrm{b}_{6}$ : Koefisien Regresi Responsiveness

$\mathrm{X}_{6}$ : Responsiveness

e : Kesalahan Penggunaan 
Berdasarkan perhitungan regresi berganda antara Compliance $\left(\mathrm{X}_{1}\right)$, Assurance $\left(\mathrm{X}_{2}\right)$, dan Kepuasan Nasabah $(\mathrm{Y})$ dan dibantu dengan alat bantu program hitung spss 20 adalah sebagai berikut:

Tabel 7. Hasil Analisis Regresi Berganda

Coefficients $^{a}$

\begin{tabular}{|c|c|c|c|c|c|c|c|c|}
\hline \multirow{2}{*}{\multicolumn{2}{|c|}{ Model }} & \multicolumn{2}{|c|}{$\begin{array}{l}\text { Unstandardized } \\
\text { Coefficients }\end{array}$} & \multirow{2}{*}{$\begin{array}{c}\text { Standar } \\
\text { dized } \\
\text { Coefficie } \\
\text { nts } \\
\text { Beta }\end{array}$} & \multirow[t]{2}{*}{$\mathrm{t}$} & \multirow[t]{2}{*}{ Sig. } & \multicolumn{2}{|c|}{$\begin{array}{l}\text { Collinearity } \\
\text { Statistics }\end{array}$} \\
\hline & & B & $\begin{array}{l}\text { Std. } \\
\text { Error }\end{array}$ & & & & $\begin{array}{c}\text { Toleran } \\
\text { ce }\end{array}$ & VIF \\
\hline \multirow{3}{*}{1} & (Constant) & 3.004 & .934 & & 3.217 & .002 & & \\
\hline & COMTOTAL & .125 & .054 & .253 & 2.330 & .022 & .501 & 1.997 \\
\hline & ASTOTAL & .344 & .082 & .458 & 4.219 & .000 & .501 & 1.997 \\
\hline
\end{tabular}

a. Dependent Variable: KTOTAL

Sumber: Hasil Penelitian, 2018 (data diolah pada SPSS 20)

Berdasarkan tabel di atas maka didapat persamaan regresi yang terbentuk pada uji regresi ini sebagai berikut:

$$
\mathrm{Y}=3,004+0.125\left(\mathrm{X}_{1}\right)+0.344\left(\mathrm{X}_{2}\right)
$$

Hasil persamaan regresi berganda tersebut diatas memberikan penjelasan bahwa:

1. Nilai konstanta sebesar 3,004 nilai tersebut dapat diartikan bahwa jika tidak dipengaruhi oleh dimensi Compliance dan Assurance maka kepuasan nasabah pada BMT Barokatul Ummah tidak akan mengalami perubahan (konstan).

2. Nilai koefisien regresi dimensi Compliance sebesar 0,125 bernilai positif, mempunyai arti bahwa tanggapan nasabah terhadap dimensi Compliance baik. Artinya jika Compliance benar-benar diberlakukan menurut syariat islam, maka akan membantu mempermudah nasabah dalam melakukan investasi pada BMT Barokatul Ummah di Kabupaten Merauke.

Economica: Jurnal Ekonomi Islam - Volume 9, Nomor 2 (2018) 
3. Nilai koefisien regresi dimensi Assurance sebesar 0.344 bernilai positif, mempunyai arti bahwa tanggapan nasabah terhadap dimensi Assurance baik. Artinya apabila BMT lebih memfokuskan dimensi Assurance, maka kepuasan nasabah pada BMT Barokatul Ummah di Kabupaten Merauke akan semakin meningkat, karena karyawan BMT ramah dan sopan terhadap nasabah, mempunyai pengetahuan yang luas tehadap produk sehingga dapat memberikan saran produk yang terbaik bagi nasabah dan menjaga kerahasian data nasabah. Sehingga membuat nasabah percaya terhadap BMT dan measa puas menabung di BMT.

\section{Pengujian Hipotesis}

\section{Uji t}

Untuk mengetahui ada tidaknya pengaruh variabel bebas terhadap variabel terikat, maka dilakukan pengujian terhadap hipotesis yang diajukan pada penelitian ini. Metode pengujian terhadap hipotesis yang diajukan dilakukan pengujian secara parsial menggunakan uji t. Uji t menunjukkan seberapa jauh pengaruh variabel independen terhadap dependen. Uji $t$ digunakan untuk menguji variabel bebas dan variabel terikat secara bersama-sama, berikut hasil uji t dengan menggunakan spss 20:

Tabel 8. Hasil Uji t

Coefficients $^{\mathrm{a}}$

\begin{tabular}{|c|c|c|c|c|c|c|c|c|}
\hline \multirow{2}{*}{\multicolumn{2}{|c|}{ Model }} & \multicolumn{2}{|c|}{$\begin{array}{l}\text { Unstandardized } \\
\text { Coefficients }\end{array}$} & \multirow{2}{*}{$\begin{array}{c}\begin{array}{c}\text { Standard } \\
\text { ized } \\
\text { Coefficie } \\
\text { nts }\end{array} \\
\text { Beta }\end{array}$} & \multirow[t]{2}{*}{$\mathbf{t}$} & \multirow[t]{2}{*}{ Sig. } & \multicolumn{2}{|c|}{$\begin{array}{c}\text { Collinearity } \\
\text { Statistics }\end{array}$} \\
\hline & & B & $\begin{array}{c}\text { Std. } \\
\text { Error }\end{array}$ & & & & Tolerance & VIF \\
\hline \multirow{3}{*}{1} & (Constant) & 3.004 & .934 & & 3.217 & .002 & & \\
\hline & COMTOTAL & .125 & .054 & .253 & 2.330 & .022 & .501 & 1.997 \\
\hline & ASTOTAL & .344 & .082 & .458 & 4.219 & .000 & .501 & 1.997 \\
\hline
\end{tabular}

Sumber: Hasil Penelitian, 2018 (data diolah pada SPSS 20) 
Uji t dilakukan untuk secara parsial apakah dimensi Compliance dan Assurance secara parsial atau masing-masing mempunyai pengaruh terhadap kepuasan nasabah.

\section{Compliance}

Dimensi Compliance berpengaruh secara positif dan signifikan terhadap kepuasan nasabah. Hal ini dapat dilihat dari $t_{\text {hitung }} 2,330>t_{\text {tabel }} 1,66088$, sedangkan nilai signifikan sebesar 0,022. Karena lebih kecil dari 0,050 sehingga Compliance berpengaruh positif dan signifikan terhadap kepuasan nasabah. Jadi bisa diasumsikan bahwa dimensi Compliance meningkat maka kepuasan nasabah juga meningkat. Artinya jika dimensi Compliance diberlakukan sesuai syariat islam di dalam BMT Barokatul Ummah akan memberikan kemudahan bagi nasabah untuk menabung sehingga kepuasan nasabah akan semakin meningkat.

\section{Assurance}

Dimensi Assurance berpengaruh secara positif dan signifikan terhadap kepuasan nasabah. Hasil dari uji $t_{\text {hitung }} 2,300>t_{\text {tabel }} 1,66088$, sedangkan nilai signifikan sebesar 0,024 lebih kecil dari 0,05. Hasil uji t menunjukan bahwa dimensi Assurance terbukti berpengaruh dan signifikan terhadap kepuasan nasabah.

\section{Uji F}

Yaitu untuk mengetahui pengaruh kualitas pelayanan $\left(\mathrm{X}_{1}\right)$, terhadap kepuasan nasabah dalam BMT Barokatul Ummah (Y). Model hipotesis yang digunakan dalam uji F ini adalah:

1. Jika tingkat signifikansi $\mathrm{F}>0,05$ atau $\mathrm{F}$ hitung $<\mathrm{F}$ tabel, maka $\mathrm{HO}$ diterima.

2. Jika tingkat signifikansi $\mathrm{F}<0,05$ atau $\mathrm{F}$ hitung $>\mathrm{F}$ tabel, maka $\mathrm{H} 0$ ditolak. 
Orin Verawati Ramadani, Abd Rahman Kadir, Abdullah Sanusi

Uji F digunakan untuk menguji variabel bebas dan variabel terikat secara bersama-sama, berikut hasil uji F dengan menggunakan spss 20:

Tabel 9. Hasil Uji $f$

\begin{tabular}{|l|l|r|r|r|r|r|}
\hline \multicolumn{2}{|l|}{ Model } & Sum of Squares & \multicolumn{1}{c|}{ df } & $\begin{array}{c}\text { Mean } \\
\text { Square }\end{array}$ & F & \multicolumn{1}{c|}{ Sig. } \\
\hline \multirow{3}{*}{1} & Regression & 172.704 & 2 & 86.352 & 37.061 & $.000^{\mathrm{b}}$ \\
\cline { 2 - 8 } & Residual & 221.347 & 95 & 2.330 & & \\
\cline { 2 - 8 } & Total & 394.051 & 97 & & & \\
\hline
\end{tabular}

Sumber: Hasil Penelitian, 2018 (data diolah pada SPSS 20)

Dimensi Compliance dan Assurance berpengaruh secara signifikan terhadap kepuasan nasabah. Hal ini terlihat dari $\mathrm{f}_{\text {hitung }} 37,061>\mathrm{f}_{\text {tabel }}$ 3,09. Sehingga dimensi Compliance dan Assurance berpengaruh positif dan signifikan terhadap kepuasan nasabah.

Dependent Variable: Kepuasan Nasabah

Berdasarkan $\mathrm{f}_{\text {tabel }}$ menunjukkan hasil perhitungan uji f diperoleh nilai $\mathrm{f}_{\text {hitung }}$ sebesar 37,061, dengan tingkat signifikan sebesar 0,00 $(<0,05)$. Maka hipotesis diterima.

\section{Koefisien Derteminan}

Koefisien kolerasi determinan digunakan untuk mengetahui besar kecilnya pengaruh antar variabel bebas dan variabel tidak bebas, dengan rumus sebagai berikut:

$\mathrm{R}=\mathrm{r}^{2} \times 100 \%$

Dimana:

R : Koefisien Determinan

r : Koefisien Korelasi

Berdasarkan hasil penelitian bahwa koefisien determinasi bertujuan untuk melihat seberapa besar pengaruh dimensi Compliance $\left(\mathrm{X}_{1}\right)$, Assurance $\left(\mathrm{X}_{2}\right)$, dilihat dari seberapa besar $\mathrm{r}^{2}$. 
Tabel 10. Hasil Koefisien Determinasi

Model Summaryb

\begin{tabular}{|l|r|r|r|r|}
\hline Model & R & R Square & $\begin{array}{c}\text { Adjusted R } \\
\text { Square }\end{array}$ & $\begin{array}{c}\text { Std. Error of the } \\
\text { Estimate }\end{array}$ \\
\hline 1 & $.662^{\mathrm{a}}$ & .438 & .426 & 1.526 \\
\hline
\end{tabular}

Sumber: Hasil Penelitian, 2018 (data diolah pada SPSS 20)

Berdasarkan tabel diatas diketahui bahwa besarnya nilai koefisien determinasi melalui tabel Adjusted $R$ Squareyaitu: 0,426, besarnya nilai tersebut dapat dijelaskan bahwa variabel terikat atau kepuasan nasabah (Y) dapat dijelaskan oleh variabel bebas Compliance $\left(\mathrm{X}_{1}\right)$, Assurance $\left(\mathrm{X}_{2}\right)$, dengan nilai sebesar 0,426 atau $42,6 \%$ dan sisanya $57,4 \%$ di jelaskan pada variabel lain yang tIdak diteliti pada penelitian ini.

\section{Pembahasan}

Berdasarkan hasil penelitian yang telah dilakukan dan diolah dengan alat bantu program SPSS 20 terbukti, bahwa dimensi Compliance dan Assurance berpengaruh secara positif dan signifikan. Artinya bahwa kepuasan nasabah akan meningkat, jika dimensi Compliance dan Assurance lebih ditingkatkan lagi. Dengan pernyataan tersebut dapat diketahui bahwa variabel dimensi Compliance dan Assurance sangat penting dalam meningkatkan kepuasan nasabah.

Dimensi Compliance dibentuk menjadi 3 indikator, yaitu: sesuai dengan hukum dan prinsip-prinsip Islam, tidak ada bunga yang diambil ataupun diberikan pada tabungan, dan ketersediaan produk investasi bagi hasil. Hasil analisis data secara statistik menunjukkan bahwa Compliance berpengaruh secara positif dan signifikan terhadap kepuasan nasabah pada BMT Barokatul Ummah di Kabupaten Merauke.

Hal ini dapat dilihat pada hasil penelitian dilapangan menunjukkan bahwa dimensi Compliance $\left(\mathrm{X}_{1}\right)$ mengalami peningkatan maka variable kepuasan nasabah juga akan meningkat. Dan apabila untuk indikator "sesuai dengan hukum dan prinsip-prinsip Islam" diterapkan di Merauke dengan

Economica: Jurnal Ekonomi Islam - Volume 9, Nomor 2 (2018) 
mayoritas penduduk adalah muslim dan non muslim. Jadi dengan adanya hukum dan prinsip-prinsip islam yang diterapkan oleh bank BMT tersebut akan memberikan pemahaman bagi nasabah tentang ketentuan-ketentuan investasi secara syariah islam, maka kepuasan nasabahnya akan meningkat.

Dimensi Assurance dibentuk menjadi 4 indikator, yaitu: karyawan yang sopan dan ramah, karyawan yang mengetahui produk BMT, BMT memberikan kerahasiaan data nasabah, dan BMT memberikan saran produk yang terbaik. Hasil analisis data secara statistik menunjukkan bahwa Assurance berpengaruh secara positif dan signifikan terhadap kepuasan nasabah pada BMT Barokatul Ummah di Kabupaten Merauke.

Hal ini dapat dilihat hasil penelitian dilapangan menunjukkan bahwa dimensi Assurance $\left(\mathrm{X}_{2}\right)$. Artinya bahwa apabila Assurance lebih ditingkatkan maka berpengaruh terhadap kepuasan nasabah pada BMT Barokatul Ummah di Kabupaten Merauke. Dan apabila untuk indikator "BMT memberikan saran produk yang terbaik" dijalankan maka akan membuat nasabah menjadi yakin akan menabung di BMT karena mempercayai karyawan dan jenis produk yang ditawarkan dengan baik, ini akan membuat nasabah akan merasa puas akan pelayanan yang diberikan oleh BMT, maka kepuasan nasabahnya akan meningkat.

Penelitian ini didukung oleh penelitian terdahulu yaitu: Febriana (2016) Dengan judul "Analisis Kualitas Pelayanan Bank Terhadap Kepuasan Nasabah Pada Bank Muamalat Indonesia Kantor Cabang Pembantu Tulungagung". Dengan hasil penelitian dimensi Assurance merupakan dimensi yang berpengaruh dominan terhadap kepuasan nasabah BMI KCP Tulungagung, sehingga dapat disimpulkan bahwa tingkat kepuasan nasabah BMI KCP Tulungagung dipengaruhi oleh kualitas pelayanan yang diberikan oleh BMI KCP Tulungagung yang terangkum kedalam 6 dimensi CARTER. 
Analisis Pengaruh Shariah Compliance dan Assurance....

\section{Simpulan}

Berdasarkan hasil penelitian, ditemukan bahwa Compliance berpengaruh positif terhadap kepuasan nasabah. Dan apabila Compliance mengalami peningkatan maka variabel kepuasan nasabah akan meningkat pula. Artinya bahwa Compliance dengan indikator "sesuai dengan hukum dan prinsip-prinsip Islam" diterapkan oleh BMT maka akan memudahkan bagi nasabah dan kepuasan nasabahnya akan meningkat.

Berdasarkan hasil penelitian, ditemukan bahwa Assurance lebih ditingkatkan maka berpengaruh terhadap kepuasan nasabah pada BMT Barokatul Ummah di Kabupaten Merauke.

Dan berdasarkan hasil penelitian Compliance dan Assurance bersamasama berpengaruh positif dan signifikan terhadap meningkatkan Kepuasan Nasabah. Apabila Compliance dan Assurance lebih ditingkatkan lagi maka kepuasan nasabah akan meningkat.

Sebaiknya BMT Barokatul Ummah lebih meningkatkan hukum dan prinsip-prinsip Islam, agar dimensi Compliance dapat di implementasikan sehingga kepuasan nasabah dapat meningkat. Bagi peneliti selanjutnya diharapkan di masa yang akan datang penelitian ini dapat digunakan sebagai salah satu sumber data untuk penelitian selanjutnya dan dilakukan penelitian yang tetap berhubungan dengan kualitas pelayanan dalam meningkatkan kepuasan nasabah (dimensi CARTER) di tempat yang berbeda dengan jumlah sampel yang lebih banyak.

Bagi peneliti selanjutnya diharapkan di masa yang akan datang penelitian ini dapat digunakan sebagai salah satu sumber data untuk penelitian selanjutnya dan dilakukan penelitian yang tetap berhubungan dengan kualitas pelayanan dalam meningkatkan kepuasan nasabah (dimensi CARTER) di tempat yang berbeda dengan jumlah sampel yang lebih banyak. 


\section{Daftar Pustaka}

Ahmad, Kamaruddin. 2004. Dasar-Dasar Manajemen Investasi Portofolio. Jakarta: Rineka Cipta.

Cahyani, Putri Dwi. 2016. "Tingkat Kepuasan Nasabah Terhadap Kualitas Layanan Perbankan Syariah Di Yogyakarta." ESENSI 6 (2): 151-62. https://doi.org/10.15408/ess.v6i2.3570.

Daryanto, Daryanto. 2011. Sari Kuliah Manajemen Pemasaran. Bandung: PT Sarana Tutorial Nurani Sejahtera.

Febriana, Nina Indah. 2016. "Analisis Kualitas Pelayanan Bank Terhadap Kepuasan Nasabah Pada Bank Muamalat Indonesia Kantor Cabang Pembantu Tulungagung." An-Nisbah: Jurnal Ekonomi Syariah 3 (1): 145-68. https://doi.org/10.21274/an.2016.3.1.145-168.

Haryanto, Resty Avita. 2013. "Strategi Promosi, Kualitas Produk, Kualitas Layanan Terhadap Kepuasan Pelanggan Pada Restoran Mcdonald's Manado." Jurnal EMBA: Jurnal Riset Ekonomi, Manajemen, Bisnis Dan Akuntansi 1 https://ejournal.unsrat.ac.id/index.php/emba/article/view/2923.

Hasanah, Uswatun. 2013. "Analisis Pengaruh Kualitas Pelayanan Pt. Bank Muamalat Indonesia Cabang Palu Terhadap Tingkat Kepuasan Nasabah." Jurnal Penelitian Ilmiah 1 (1).

Muchtiar, Yesmizarti, Dessi Mufti, and Ike Irma Suryani. 2012. "Analisis Service Quality Pada Layanan Asurance." Jurnal Teknik Industri Universitas Bung Hatta http://ejurnal.bunghatta.ac.id/index.php?journal=JTIUBH\&page=article\&op=view\&path\%5B\%5D=2249.

Parasuraman, A, Valarie A Zeithaml, and Leonard L. Berry. 1988. "Servqual: A Multiple-Item Scale For Measuring Consumer Perc." Journal of Retailing 64 (1): 12-40. https://search.proquest.com/openview/7d007e04d78261295e5524f 15bef6837/1?pq-origsite=gscholar\&cbl=41988.

Rangkuti, Freddy. 1997. Riset Pemasaran. Cet. 2. Jakarta: Gramedia Pustaka Utama.

Rohmati, Dani, and Sunan Fanani. 2016. "Implemtasi Kualitas Pelayanan Pendekatan Carter Dan Pengaruhnya Terhadap Kepuasan Ujks 
Koperasi Karyawan." Jurnal Ekonomi Syariah Teori Dan Terapan 3 (3): 203-18.

Sekaran, Uma. 2006. Metode Penelitian Untuk Bisnis. Jakarta: Salemba Empat.

Shofani, Pritandra Chusnuludin. 2015. "Analisis Pengaruh Dimensi Kualitas Pelayanan Dan Kualitas Produk Terhadap Kepuasan Nasabah (Studi Kasus Pada PT Bank Brisyariah Kantor Cabang Semarang)." Politeknik Negeri Semarang.

Sinambela, Sinambela, and Poltak Lijan. 2014. Metodologi Penelitian Kuantitatif. Yogyakarta: Graha Ilmu.

Sudaryono, Sudaryono. 2016. Manajemen Pemasaran: Teori Dan Implementasi. Yogyakarta: Andi.

Sujarweni, V. Wiratna. 2015. Metodologi Penelitian Bisnis \&amp; Ekonomi. Yogyakarta: Pustaka Baru Press. 
